\title{
Absence of Sperm Factors as in the Parthenogenesis Does Not Interfere on Bovine Embryo Sensitiveness to Heat Shock at Pre-Implantation Stage
}

\author{
LSA Camargo ${ }^{1,2}$, F Paludo ${ }^{2}$, MM Pereira ${ }^{3}$, S Wohlres-Viana ${ }^{3}$, MM Gioso ${ }^{2}$, BC Carvalho ${ }^{1,2}$, CCR Quintao ${ }^{1}$ and JHM Viana $^{1,2}$ \\ ${ }^{1}$ Brazilian Agricultural Research Corporation-Embrapa, Juiz de Fora, MG, Brazil; ${ }^{2}$ UNIFENAS, Alfenas, MG, Brazil; ${ }^{3}$ Federal University of Juiz \\ de Fora, Juiz de Fora, MG, Brazil
}

\begin{abstract}
Contents
Oocyte has been considered the major contributor for embryo thermo-tolerance. However, it was shown that sperm factors can be transferred to the oocyte during fertilization, raising the question of whether the absence of such factors could interfere on embryo thermo-tolerance. In this study, we used parthenogenesis to generate bovine embryos without spermatozoa in order to test whether the absence of sperm factors could influence their thermo-sensitiveness at early stages. In vitro fertilized (IVF) and parthenogenetic (PA) embryos at $44 \mathrm{~h}$ postinsemination/chemical activation were exposed to $38.5^{\circ} \mathrm{C}$ (control) or $41^{\circ} \mathrm{C}$ (heat shock) for $12 \mathrm{~h}$ and then developed for $48 \mathrm{~h}$ and up to blastocyst stage. Apoptosis index and expression of PRDX1, GLUT1, GLUT5 and IGF1r genes in blastocysts derived from heat-shocked embryos were also evaluated. The heat shock decreased the blastocyst rate at day seven $(p<0.05)$ for IVF embryos and at day eight $(\mathrm{p}<0.01)$ for both IVF and PA embryos. Total cell number was not affected by heat shock in IVF and PA blastocysts, but there was an increased proportion $(\mathrm{p}<0.05)$ of apoptotic cells in heat-shocked embryos when compared to controls. There was no interaction $(\mathrm{p}>0.05)$ between method of activation (IVF and PA) and temperature $\left(38.5^{\circ} \mathrm{C}\right.$ or $\left.41.5^{\circ} \mathrm{C}\right)$ for all developmental parameters evaluated. Expression of GLUT1 gene was downregulated $(\mathrm{p}<0.05)$ by heat shock in both IVF and PA blastocyst whereas expression of GLUT5 and IGF1r genes was downregulated $(\mathrm{p}<0.05)$ by heat shock in PA blastocysts. Those data show that the heat shock affects negatively the embryo development towards blastocysts stage, increases the apoptotic index and disturbed the expression of some genes in both IVF and PA embryos, indicating that the presence or absence of sperm factors does not influence the sensitivity of the bovine embryo to heat shock.
\end{abstract}

\section{Introduction}

Heat stress is one of the major problems for cattle fertility (Dobson et al. 2001), and much of its effects in the reduction of fertility is due to the deleterious effect of elevate temperature on embryo developmental ability. Embryos at zygote and 2-cell stage are more sensitive to heat shock than at morula stage (Ealy et al. 1995; Sakatani et al. 2012) and become more tolerant to high temperature as they progress to more advanced stages (Hansen 2007). Eberhardt et al. (2009) showed that embryos are more sensitive to heat shock at 12 and $48 \mathrm{~h}$ than at $96 \mathrm{~h}$ post-insemination, decreasing the blastocyst production. This shift on thermo-tolerance coincides with the major activation of embryo genome (EGA) that occurs between 8- and 16-cell stages in cattle, when embryos increase their transcriptional activity, becoming more capable to adapt themselves to changes of surrounding environment. Before EGA embryo relies on oocyte's mRNAs and proteins stored in its cytoplasm to proceed with development (Memili and First 2000). This is one of the reasons why the oocyte has been considered to play a key role on embryo thermo-tolerance before EGA.

Using the greater ability of Bos indicus breeds to cope with heat shock than Bos taurus ones, earlier study suggested that the oocyte source $(B$. indicus) plays the main role on embryo thermo-tolerance (Block et al. 2002). Similar finding was reported by Satrapa et al. (2011) with Holstein $\times$ Gir (B. indicus) embryos. These studies indicate that the contribution of oocyte to embryo thermo-tolerance could be more important than that of sperm. However, it has been shown that spermatozoa may contribute to the early embryo development. Ostermeier et al. (2004) showed the presence of several transcripts in human spermatozoa, some of them implicated in embryogenesis and response to stress. MicroRNAs were also detected in mammalian spermatozoa (Ostermeier et al. 2005; Curry et al. 2009; Sendler et al. 2013) and may play a role in early embryo development (Dadoune 2009; Grandjean and Rassoulzadegan 2009; Puri et al. 2010). Such spermatic mRNAs or microRNAs could modulate the transcriptional activity post-fertilization (Dadoune 2009). In this sense, it may be argued that spermatozoa factors can be required for post-fertilization embryo development and, thus, could have some influence on embryo thermo-tolerance at earlier stages.

To test whether sperm factors can influence the embryo thermo-tolerance, we used parthenogenetic and in vitro fertilized embryos. Because there is no male participation on parthenogenesis, no sperm factors are present in such embryos. Moreover, parthenogenesis can be induced successfully in bovine oocytes using ionomycin (Lagutina et al. 2004). Thus, in this study, we evaluated the effect of heat shock on development, apoptosis and gene expression in both in vitro fertilized and parthenogenetic bovine embryos, in order to evaluate the sensitiveness of embryos to elevated temperature in the absence of sperm factors.

\section{Materials and Methods}

All chemicals were from Sigma Chemical (St. Louis, MO, USA) unless stated otherwise. 


\section{Experimental design}

The first experiment evaluated the in vitro development and apoptosis index of in vitro fertilized (IVF) and parthenogenetic (PA) embryos post-heat shock. For that, IVF and PA denuded embryos at $44 \mathrm{~h}$ postinsemination/activation (hpia) were randomly allocated in control or heat shock treatments, performing four groups: in vitro fertilized (IVF-C), in vitro fertilized heatshocked (IVF-HS), parthenogenetic (PA-C) and parthenogenetic heat-shocked (PA-HS). Heat shock was performed exposing embryos at $41^{\circ} \mathrm{C}$ for $12 \mathrm{~h}$ under $5 \% \mathrm{CO}_{2}, 5 \% \mathrm{O}_{2}$ and $90 \% \mathrm{~N}_{2}$. After heat shock, embryos were returned to the same environmental conditions of control groups $\left(38.5^{\circ} \mathrm{C}\right.$ at $5 \% \mathrm{CO}_{2}, 5 \%$ $\mathrm{O}_{2}$ and $90 \% \mathrm{~N}_{2}$ ). Proportion of embryos at $\leq 3-$, 4- to 7 and $\geq 8$-cell stages was evaluated at 0,24 and 48 h postbeginning of heat shock (equivalent to 44, 68 and 92 hpia). Blastocyst rate was evaluated at day seven (168 hpia) and eight (192 hpia) and apoptosis index in blastocyst at day eight. Fourteen replicates were performed with 2468 presumptive zygotes.

The second experiment compared the relative gene expression between IVF-C and IVF-HS blastocysts and between PA-C and PA-HS blastocysts at day eight postinsemination or activation. The genes evaluated were Peroxiredoxin 1 (PRDX1), Solute carrier family 2 [facilitated glucose transporter], member 1 (GLUT1), Solute carrier family 2 [facilitated glucose transporter], member5 (GLUT5) and Insulin-like growth factor 1 receptor (IGF1r). Three replicates were performed using pools of 10 blastocysts per group.

\section{Collection and in vitro maturation of oocytes}

Ovaries from predominantly B. indicus cross-bred cows were obtained at a local slaughterhouse (Fripai, Juiz de Fora, MG, Brazil) and transported to the laboratory in saline solution $(0.9 \% \mathrm{NaCl}$ with $0.1 \mathrm{~g} / 1$ streptomycin $)$ at $34-36^{\circ} \mathrm{C}$. Follicles with $2-8 \mathrm{~mm}$ diameter were aspirated, and the COCs with more than three compact layers of cumulus cells and oocyte with homogeneous cytoplasm were randomly allocated to the groups, according to the experimental design. In vitro maturation was performed in tissue culture medium (TCM-199; Gibco Life Technologies, Inc., Grand Island, NY, USA) supplemented with $20 \mu \mathrm{g} / \mathrm{ml}$ follicle stimulating hormone (FSH; Pluset, Calier, Barcelona, Spain), $0.36 \mathrm{~mm}$ sodium pyruvate, $10 \mathrm{~mm}$ sodium bicarbonate and $50 \mathrm{mg} / \mathrm{ml} \mathrm{streptomycin} /$ penicillin in a humidified atmosphere of $5 \% \mathrm{CO}_{2}$ in air and $100 \%$ humidity.

\section{Fertilization, parthenogenesis, in vitro culture and heat shock}

A pool of frozen/thawed motile spermatozoa from three Holstein bulls was obtained after one centrifugation at $9000 \times \boldsymbol{g}$ for $5 \mathrm{~min}$ in Percoll discontinuous density gradient (45 and 90\%). The pellet was centrifuged again at $9000 \times \boldsymbol{g}$ for $3 \mathrm{~min}$ in Fert-TALP medium. In vitro fertilization was performed in 1262 in vitro-matured oocytes using $2 \times 10^{6}$ spermatozoa $/ \mathrm{ml}$ for $21 \mathrm{~h}$ in $100 \mu \mathrm{l}$ drops of Fert-TALP supplemented with $20 \mu \mathrm{g} /$ $\mathrm{ml}$ of heparin and $6 \mathrm{mg} / \mathrm{ml}$ of fatty acid free BSA fraction $\mathrm{V}$, covered with mineral oil, in a humidified atmosphere of $5 \% \mathrm{CO}_{2}$ and $38.8^{\circ} \mathrm{C}$ in air. After in vitro fertilization, the presumptive zygotes were denuded by vortex in $0.1 \%$ hyaluronidase solution.

Parthenogenesis was induced by ionomycin and 6DMAP. After in vitro maturation, oocytes $(\mathrm{N}=1206)$ were denuded by vortex in $0.1 \%$ hyaluronidase solution and activated by exposing them to $4.8 \mu \mathrm{M}$ ionomycin for 5 min followed by $4 \mathrm{~h}$ in $2 \mathrm{~mm}$ 6-DMAP. After in vitro fertilization or parthenogenesis, the presumptive zygotes were cultured in a modified CR2aa medium with $2.5 \%$ of foetal calf serum (Nutricell Nutrientes Celulares, Campinas, SP, Brazil) under $5 \% \mathrm{CO}_{2}, 5 \% \mathrm{O}_{2}$ and $90 \%$ $\mathrm{N}_{2}$ at $38.5^{\circ} \mathrm{C}$ until 44 hpia, when they were randomly allocated into control $\left(38.5^{\circ} \mathrm{C}\right)$ or heat shock $\left(41^{\circ} \mathrm{C}\right)$ groups. After $12 \mathrm{~h}$ of heat shock, embryos returned to $38.5^{\circ} \mathrm{C}$.

\section{Apoptosis analysis}

Blastocysts $(\mathrm{N}=80)$ at day eight from different replicates were submitted to terminal deoxynucleotidyl transferase-mediated dUTP-digoxigenin nick end-labelling (TUNEL) staining using a commercially available kit (Dead End Fluorimetric TUNEL System; Promega, Madison, WI, USA) according to manufacturer's instructions. Briefly, embryos were fixed in $4 \%$ paraformaldehyde at $4{ }^{\circ} \mathrm{C}$ and then permeabilized with $0.2 \%$ Triton X-100 (Promega), both in PBS (Nutricell). Positive control embryos were previously treated with 8 units $/ \mathrm{ml}$ DNase (Promega). After permeabilization, positive control and target samples were incubated in $100 \mu 1$ drops with reagent mix containing enzyme solution (terminal deoxynucleotide transferase enzyme) and $90 \%$ staining solution (dUTP fluorescein conjugate) for $1 \mathrm{~h}$ at $37^{\circ} \mathrm{C}$ in a dark humid chamber. Negative control embryos were incubated only in the staining solution without enzyme solution. After that, embryos were stained with Vectashield (Vector Laboratories Inc., Burlingame, CA, USA) plus 4'6-diamidino-2-phenylindole (DAPI) and mounted on slides for evaluation by fluorescence microscopy. Total cell number and apoptotic cell number per embryo (80 embryos from four different replicates) were counted, and apoptotic cell index was calculated as the proportion of apoptotic cell/ total cell number.

\section{Total RNA extraction and reverse transcription in blastocysts}

Blastocysts $(\mathrm{N}=120)$ at day eight from different replicates were frozen in liquid nitrogen and then pooled for RNA extraction. Total RNA was extracted from three pools of ten blastocysts per treatment using the RNeasy 
Micro Kit (Qiagen GmbH, Hilden, Germany), according to the manufacturer's instructions, and treated with DNAse I (27 units for $15 \mathrm{~min}$ at room temperature). The RNA samples were reversely transcribed using the SuperScript III First-Strand Synthesis Supermix (Invitrogen, Carlsbad, CA, USA) according to the manufacturer's instructions, using oligo $(\mathrm{dT})_{20}$ primers, dNTP mix, Superscript III RT, RNaseOUT, $\mathrm{MgCl}_{2}$, RT buffer in a final volume of $20 \mu \mathrm{l}$. Samples were first incubated at $65^{\circ} \mathrm{C}$ for $5 \mathrm{~min}$ and then for $50^{\circ} \mathrm{C}$ for $50 \mathrm{~min}$. The reaction was terminated at $85^{\circ} \mathrm{C}$ for $5 \mathrm{~min}$ and then chilled on ice. After that, RNase $\mathrm{H}$ was added to the samples and incubated at $37^{\circ} \mathrm{C}$ for $20 \mathrm{~min}$. The RNA and cDNA quantification and purity for each sample was performed using $1 \mu 1$ of sample in spectrophotometer nd-100 (Nanodrop, Wilmington, DE, USA).

\section{Relative quantification by Real-Time PCR}

Relative quantification was performed in triplicate using Real-Time PCR (ABI Prism 7300 Sequence Detection Systems; Applied Biosystem, Foster City, CA, USA). Reactions were prepared using a mixture of Power SYBR Green PCR Master Mix (Applied Biosystems), primers, nuclease-free water and cDNA. The target genes were PRDX1, GLUT1, GLUT5 and IGF1r. The amount of cDNA used in the reactions ranged according to the optimal concentration previously identified. For IGF1r, GLUT1, GLUT5, beta-ACTIN $(A C T B)$ and glyceraldehyde-3-phosphate dehydrogenase $(G A P D H)$, $400 \mathrm{ng}$ cDNA was used, and for $P R D X 1,800 \mathrm{ng}$ cDNA was used. Expressions of $A C T B$ and $G A P D H$ genes were used as endogenous references. The cDNA template was denatured at $95^{\circ} \mathrm{C}$ for $10 \mathrm{~min}$, followed by 45 cycles of $95^{\circ} \mathrm{C}$ for $15 \mathrm{~s}$, gene-specific primer annealing temperature for $30 \mathrm{~s}$ (Table 1) and elongation at $60^{\circ} \mathrm{C}$ for $30 \mathrm{~s}$. After each PCR run, a melting curve analysis was performed to confirm that a single-specific product was generated. No-template controls (NTC), comprised of the PCR reaction mix without DNA template, were also run with each primer to confirm the absence of contaminations. Primer efficiency was calculated using
LinRegPCR software (Ramakers et al. 2003) for each reaction. The primer efficiency was 1.89, 1.85, 1.82, 1.95, 1.97 and 1.93 for ACTB, GAPDH, PRDX1, GLUT1, GLUT5 and IGFIr genes. Calculations of relative quantification were performed by the REST software (Pfaffl et al. 2002) based on comparative Ct quantification. Expressions of IVF control and PA control blastocysts were used as calibrators to calculate the relative abundance of transcripts between control and heat shock groups, respectively. Values are shown as nfold difference relative to the calibrator.

\section{Statistics}

Data of proportion of embryos at $\leq 3-, 4$ - to 7 - and $\geq 8$ cell stages at 0,24 and $48 \mathrm{~h}$ post-beginning of heat shock, proportion of blastocyst at day seven and at day eight, total number of cells and index of apoptotic cells were evaluated by analysis of variance using the generalized linear model procedure (GLM) in SAS (version 9.1; SAS Institute Inc., Cary, NC, USA). A $2 \times 2$ factorial analysis was performed considering two temperatures $\left(38.5^{\circ}\right.$ or $\left.41^{\circ} \mathrm{C}\right)$ and two methods of activation (IVF or PA) as source of variation. Means were compared by Student-Newman-Keuls test. In the second experiment, analysis of gene expression between IVF-C and IVF-HS and between PA-C and PA-HS embryos were performed by REST software using the pairwise fixed reallocation randomization test (Pfaffl et al. 2002). Differences were considered significant at the $95 \%$ confidence level $(p<0.05)$. All data are presented as mean \pm SEM.

\section{Results \\ Experiment 1}

The first experiment evaluated the development and apoptosis index of heat-shocked IVF and PA embryos. The overall cleavage rate (embryos with $\geq 2$-cells) at 44 hpia was similar between IVF and PA embryos (76.2 \pm 0.7 and $74.5 \pm 3.7 \%$, respectively; $p>0.05$ ). There was neither difference on proportion of $\leq 3-, 4$ - to

Table 1. Primer sequences used for relative gene expression analysis by real-time polymerase chain reaction of in vitro fertilized and parthenogenetic embryos, exposed or not to heat shock

\begin{tabular}{|c|c|c|c|c|}
\hline Gene symbol & Primer Sequence $\left(5^{\prime}-3^{\prime}\right)$ & Annealing temperature $\left({ }^{\circ} \mathrm{C}\right)$ & Fragment Size (bp) & $\begin{array}{l}\text { GenBank Accession } \\
\text { Number or Reference }\end{array}$ \\
\hline$A C T B$ & $\begin{array}{l}\mathrm{F} \text {-GACATCCGCAAGGACCTCTA } \\
\mathrm{R} \text {-ACATCTGCTGGAAGGTGGAC }\end{array}$ & 53 & 205 & NM_173979 \\
\hline GAPDH & $\begin{array}{l}\text { F-CCAACGTGTCTGTTGTGGATCTGA } \\
\text { R-AGCTTGACAAAGTGGTCGTTGAG }\end{array}$ & 53 & 217 & Mourot et al. (2006) \\
\hline$P R D X 1$ & $\begin{array}{l}\text { F-ATGCCAGATGGTCAGTTCAAG } \\
\text { R- CCTTGTTTCTTGGGTGTGTTG }\end{array}$ & 53 & 224 & Mourot et al. (2006) \\
\hline$I G F 1 r$ & $\begin{array}{l}\text { F-CGCTGGATGTCCCCTGAGT } \\
\text { R-GTTGTCCGGCTTGTCCAGAA }\end{array}$ & 53 & 180 & Bertolini et al. (2002) \\
\hline GLUT1 & $\begin{array}{l}\text { F-CCAAGGATCTCTCAGAGCACAG } \\
\text { R-TTCTTCTGGACATCACTGCTGG }\end{array}$ & 53 & 110 & Sagirkaya et al. (2007) \\
\hline GLUT5 & $\begin{array}{l}\text { F-CATGGTGGCGGGTACTGTTC } \\
\text { R-CGCAAAAATGACGAAGCTGTAAG }\end{array}$ & 53 & 103 & de Camargo et al. (2005) \\
\hline
\end{tabular}


7- and $\geq 8$-cell stages embryos among IVF-C, IVF-HS, PA-C and PA-HS groups at 0,24 and $48 \mathrm{~h}$ postbeginning of heat shock, nor interaction among them ( $\mathrm{p}>0.05 ;$ Fig. 1). In all groups, the proportion of embryos at 4- to 7-cell stages reduced from 0 to $48 \mathrm{~h}$ post-beginning of heat shock, whereas the proportion of embryos at $\geq 8$-cell stages increased (Fig. 1). However, the heat shock decreased the blastocyst rate (Table 2) at day seven $(\mathrm{p}<0.05)$ for IVF embryos and at day eight $(p<0.01)$ for both IVF and PA embryos; there was no interaction $(\mathrm{p}>0.05)$ between temperature and method of activation. In vitro fertilization or parthenogenesis had no effect $(\mathrm{p}>0.05)$ on blastocyst production (Table 2).

Heat shock at 44 hpia did not affect $(p>0.05)$ the total cell number but increased $(\mathrm{p}<0.05)$ the propor-

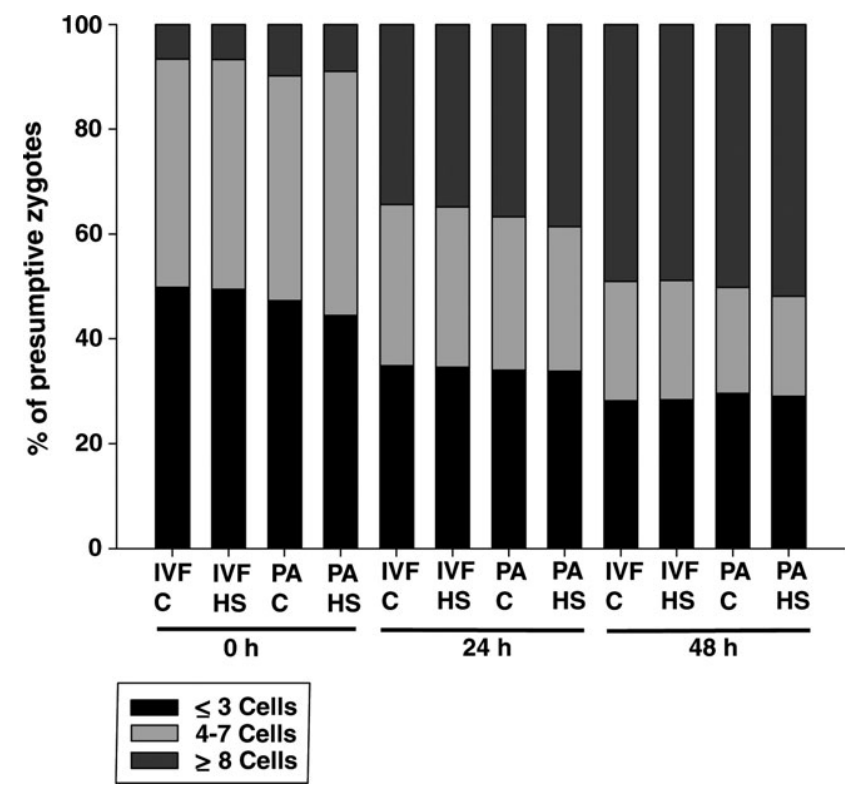

Fig. 1. Proportion of embryos at $\leq 3$-, 4 - to 7 - and $\geq 8$-cell stages at 0 , 24 and $48 \mathrm{~h}$ post-beginning of heat shock (equivalent to 44,68 and $92 \mathrm{~h}$ post-insemination/activation) for in vitro fertilized control (IVF$\mathrm{C}, \mathrm{n}=633$ ), in vitro fertilized heat-shocked (IVF-HS, $\mathrm{n}=629$ ), parthenogenetic control (PA-C, $\mathrm{n}=600)$ and parthenogenetic heatshocked (PA-HS, $\mathrm{n}=606$ ) groups. No difference was found among groups $(\mathrm{p}>0.05)$. Values are shown as proportion of presumptive zygotes tion of apoptotic cells in blastocysts at day eight in both IVF-HS and PA-HS groups. No effect $(\mathrm{p}>0.05)$ of in vitro fertilization or parthenogenesis was found on total cell number and apoptosis index, as well as no interaction $(\mathrm{p}>0.05)$ between method of activation and temperature (Table 3).

\section{Experiment 2}

Significant differences on gene expression between control and heat-shocked embryos were detected in both IVF and PA groups. Lower expression of GLUT1 gene $(p<0.05)$ was found in heat-shocked IVF embryos (Fig. 2a), and lower expression of GLUT1, GLUT5 and IGF1r genes $(\mathrm{p}<0.05)$ was found in heat-shocked PA embryos (Fig. 2b). No significant difference on expression of $P R D X 1$ gene was found.

\section{Discussion}

As early embryos depend upon mRNA and proteins stored in oocyte's cytoplasm, it is a common sense that the oocyte plays the most important role on thermotolerance of embryos before EGA. However, recently attention has been given to the role of sperm on early embryo development. At fertilization, spermatozoa can transfer mRNAs, small non-coding RNAs and other sperm factors to the oocyte, which can contribute to post-fertilization events (Kumar et al. 2013) acting, for example, as an epigenetic modifier (Dadoune 2009). Some of transcripts found in human spermatozoa encodes proteins that play a role on early embryonic development (Siffroi and Dadoune 2001; Hamatani 2012; Jodar et al. 2013), and some of them are implicated in stress response as heat shock transcription factor 2, heat shock $70 \mathrm{kDa}$ protein 1-like and DnaJ (Hsp40) homolog, subfamily B, member 1 (DNAJB1) (Ostermeier et al. 2004).

We found in the current study that the heat shock at the beginning of the development decreased the blastocyst rate of in vitro fertilized embryos, as reported elsewhere (Ealy et al. 1995; Eberhardt et al. 2009; Sakatani et al. 2012). But here we hypothesized that if bovine sperm have important factors transferred to oocyte at fertilization, the absence of those factors could

Table 2. Blastocyst rates at days seven and eight post-insemination/activation according to the number of presumptive zygotes for in vitro fertilized (IVF) or parthenogenetic (PA) embryos exposed (Heat Shock) or not (Control) to heat shock at 44 h post-insemination/activation

\begin{tabular}{|c|c|c|c|c|c|c|}
\hline & \multicolumn{2}{|c|}{ Blastocysts 168 h (\%) } & \multirow[b]{2}{*}{ Overall $(\%)$} & \multicolumn{2}{|c|}{ Blastocysts 192 h (\%) } & \multirow[b]{2}{*}{ Overall $(\%)$} \\
\hline & IVF & PA & & IVF & PA & \\
\hline Control & $24.3 \pm 2.0^{\mathrm{a}}$ & $21.6 \pm 1.5$ & $22.9 \pm 1.2^{\mathrm{a}}$ & $32.4 \pm 1.9^{\mathrm{a}}$ & $30.0 \pm 1.7^{\mathrm{a}}$ & $31.2 \pm 1.3^{\mathrm{c}}$ \\
\hline Heat shock & $17.4 \pm 2.2^{b}$ & $18.2 \pm 1.8$ & $17.8 \pm 1.4^{\mathrm{b}}$ & $23.0 \pm 2.1^{\mathrm{b}}$ & $22.6 \pm 2.0^{\mathrm{b}}$ & $22.8 \pm 1.4^{\mathrm{d}}$ \\
\hline Overall (\%) & $20.8 \pm 1.6$ & $19.9 \pm 1.2$ & & $27.7 \pm 1.6$ & $26.3 \pm 1.5$ & \\
\hline
\end{tabular}

Means with different superscripts letters in the same column differs. $\mathrm{a}, \mathrm{b}-\mathrm{p}<0.05 ; \mathrm{c}, \mathrm{d}-\mathrm{p}<0.001$. No significant interaction was found between method of activation (IVF or PA) and temperature (control: $38.5^{\circ} \mathrm{C}$ or heat shock: $41^{\circ} \mathrm{C}$ ). IVF control: $\mathrm{n}=633$ presumptive zygotes, $\mathrm{IVF}$ heat shock: $\mathrm{n}=629$; PA control: $\mathrm{n}=600$; PA heat shock: $\mathrm{n}=606$. Means are shown as mean \pm SEM. 
Table 3. Total cell number and apoptosis index of blastocysts derived from in vitro fertilized (IVF) or parthenogenetic (PA) embryos exposed (Heat Shock) or not (Control) to heat shock at $44 \mathrm{~h}$ post-insemination/activation

\begin{tabular}{|c|c|c|c|c|c|c|}
\hline & \multicolumn{2}{|c|}{ Total cell number } & \multirow[b]{2}{*}{ Overall } & \multicolumn{2}{|c|}{ Apoptosis index (\%) } & \multirow[b]{2}{*}{ Overall } \\
\hline & IVF & PA & & IVF & $\mathrm{PA}$ & \\
\hline Control & $105.4 \pm 4.9$ & $104.5 \pm 4.8$ & $104.9 \pm 3.4$ & $13.5 \pm 0.9^{\mathrm{a}}$ & $13.7 \pm 0.9^{\mathrm{a}}$ & $13.6 \pm 0.66^{\mathrm{a}}$ \\
\hline Heat shock & $111.7 \pm 6.4$ & $96.8 \pm 16.9$ & $104.2 \pm 3.8$ & $16.7 \pm 0.9^{\mathrm{b}}$ & $17.0 \pm 0.9^{b}$ & $16.8 \pm 0.69^{b}$ \\
\hline Overall & $108.6 \pm 4.0$ & $100.6 \pm 3.1$ & & $15.1 \pm 0.73$ & $15.3 \pm 0.71$ & \\
\hline
\end{tabular}

Means with different superscripts letters in the same column differs. $\mathrm{a}, \mathrm{b}-\mathrm{p}<0.05$. No significant interaction was found between method of activation (IVF or PA) and temperature (control: $38.5^{\circ} \mathrm{C}$ or heat shock: $41^{\circ} \mathrm{C}$ ). IVF control: $n=20$, IVF heat shock: $n=20$; PA control: $n=20$; PA heat shock: $n=20$. Means are shown as mean \pm SEM.
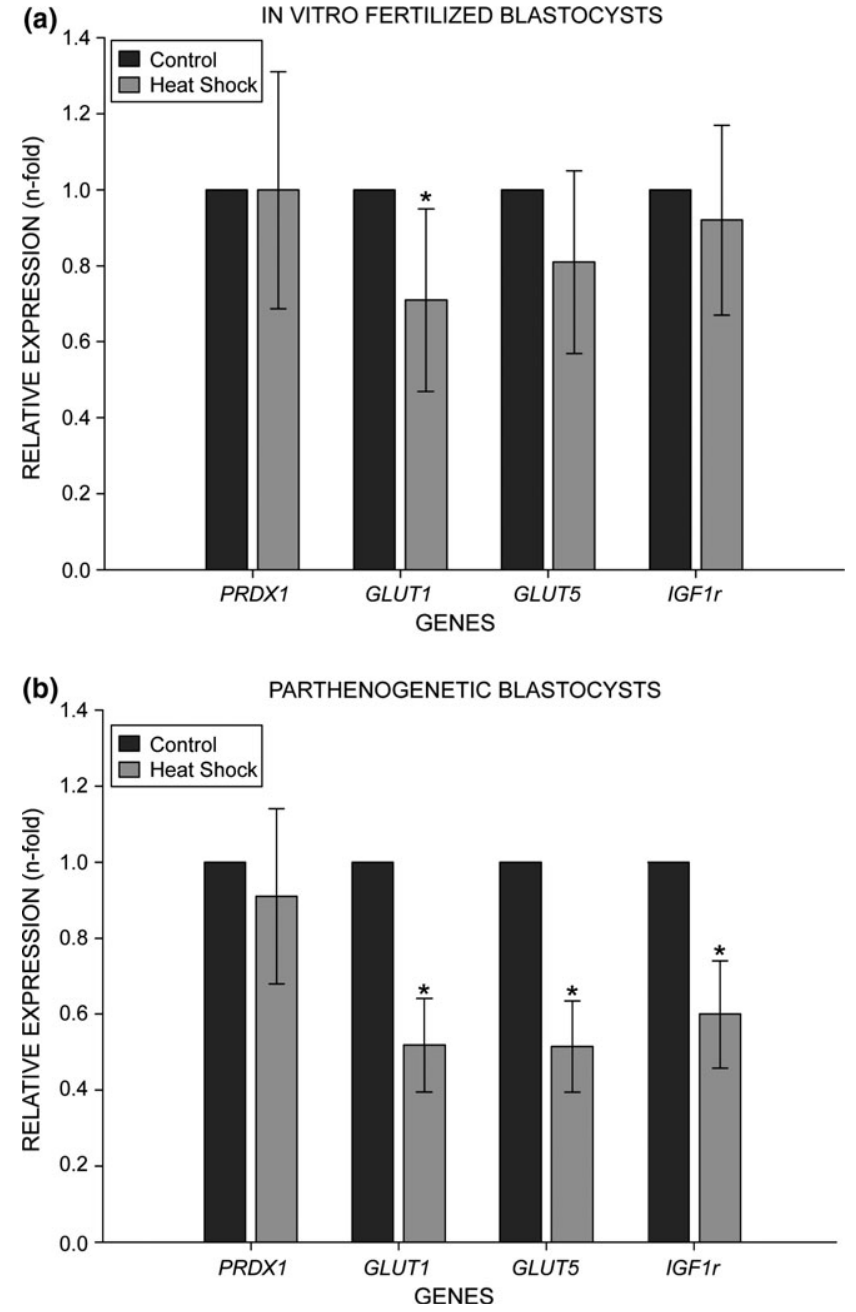

Fig. 2. Relative gene expression in blastocysts derived from in vitro fertilized (Panel a) or parthenogenetic (Panel b) heat-shocked embryos. Columns with asterisk $(*)$ within gene differ $(\mathrm{p}<0.05)$ between control $\left(38.5^{\circ} \mathrm{C}\right)$ and heat shock $\left(41{ }^{\circ} \mathrm{C}\right)$ groups. Data of control group were used as calibrator $(=1)$, and means of heat shock group are shown as fold change (mean $\pm \mathrm{SEM}$ ) relative to the calibrator

implicate a higher sensitivity of embryos to heat shock. To test this hypothesis, we exposed parthenogenetic embryos, which activation has no male participation, to an elevated temperature at $44 \mathrm{~h}$ post-activation and compared them with in vitro fertilized embryos at the same conditions. We found that the origin of the embryos, either from fertilization or parthenogenesis, has no influence on heat shock effects on further embryo development, indicating that the absence of sperm factors, as in parthenogenetic embryos, has no impact on embryo thermo-sensitiveness. In other words, spermatozoa seem to play a minor, if any, role on embryo pre-implantation development under heat shock. This is in agreement with data reported by Block et al. (2002) and Satrapa et al. (2011). These authors found that the level of thermo-tolerance of in vitro fertilized cross-bred embryos was more dependent on the origin of the oocyte than on the origin of spermatozoa when used sperm from thermo-tolerant breeds to fertilize oocytes from thermo-sensitive breeds and vice versa. Taking together, these data confirm that oocyte's contribution to the embryo is more important for thermo-tolerance before EGA than sperm's contribution.

The effect of heat shock on the development of IVF and PA bovine embryos up to blastocyst stage found in Experiment 1 differs to some reports with porcine embryos (Isom et al. 2007, 2009) that did not find any negative effect of heat shock on the development of parthenogenetic embryos, but it is in agreement with another study that reported a lower development rate of parthenogenetic heat-shocked porcine embryos (Jin et al. 2007). Thus, it is not clear if heat shock can impair the development of porcine parthenogenetic embryos in the same way as observed for bovine embryos.

In the current study, we found that the proportion of embryos at 4- to 7- and $\geq 8$-cell stages within the $48 \mathrm{~h}$ post-beginning of heat shock (i.e. until $92 \mathrm{~h}$ postinsemination/activation) is similar to the control group for both in vitro fertilization and parthenogenesis. As time goes on, more embryos progress towards $\geq 8$-cell stages within $48 \mathrm{~h}$ post-beginning of heat shock, with the same proportion of control ones and regardless the method of activation. However, the proportion of presumptive zygotes that developed up to blastocyst stage was significantly lower after heat shock. As the major EGA occurs between 8- to 16-cell stages, the development until those stages is highly dependent on proteins and mRNA stored in the oocyte cytoplasm, 
which suggests that subtle changes on external environment may have low impact on embryo development by 8 -cell stage. This may be one of the reasons why the effect of heat shock on embryos at 44 hpia (with 2-7 cells) could not be perceived before EGA but only on later (blastocyst) stages. Another possible reason is the lower capacity of early embryos to undergo apoptosis. Apoptosis is a process of cell death required to eliminate damaged cells, but its high incidence is associated to embryos with low quality (Hardy 1997), being necessary to keep the apoptotic index below a certain threshold to avoid the developmental arrest (Haouzi and Hamamah 2009). Apoptosis can be induced by heat shock in embryonic cells (Hansen 2007); however, bovine embryos before 8- to 16-cell stages are refractory to apoptosis (Matwee et al. 2000; Paula-Lopes and Hansen 2002). This means that even under heat shock, the effects of apoptosis on embryo viability will rarely be perceived before 8- to 16-cell stages. Nevertheless, we found that the effects on apoptosis of heat shock applied before 8- to 16-cell stages can be noted at blastocyst stage, regardless the origin of embryos (IVF or PA). Higher apoptotic index was found in blastocysts derived from heat-shocked embryos at 44 hpia (when they were predominantly between 2- and 4-cell stages). Those findings suggest that even though heat shock can rarely induce apoptosis before 8- to 16-cell stages, it can increase the proportion of apoptotic cells on later stages, namely blastocyst stage. Yet we do not know whether this incidence of apoptosis in blastocysts will be high enough to compromise embryo quality as it is a mechanism that embryo has to eliminate damaged cells in order to keep its viability.

In a second experiment, we compared the expression of some genes between blastocysts derived from heatshocked or control embryos for in vitro fertilization and for parthenogenesis. The genes analysed encode the PRDX1, a member of peroxiredoxin family important for cellular defence against oxidative stress (Immenschuh and Baumgart-Vogt 2005); GLUT1 and GLUT5, glucose and fructose transporters (Pantaleon and Kaye 1998) important for passive sugar uptake and, consequently, for embryo metabolism; and IGF1r protein, receptor that intermediates the actions of IGF1 (Pantaleon and Kaye 1996).

We found that in both IVF and PA embryos, the relative expression of some genes was disturbed by heat shock. Heat-shocked IVF blastocysts displayed lower expression of GLUT1 gene. Glucose metabolism and uptake is increased from 16-cell stage on but markedly at blastocyst stage (Rieger et al. 1992). Lower expression of GLUT1 gene may result in lower glucose uptake, interfering on blastocysts metabolism and consequently on embryo viability. Heat-shocked PA blastocysts displayed lower expression of GLUT5 and IGF1r genes. Fructose can be used as source of energy for bovine embryos and improves in vitro embryo development (Barcelo-Fimbres and Seidel 2007). The lower expression of GLUT5 gene in heat-shocked PA embryos indicates that those embryos may not be able to make full use of this hexose when available in culture medium. IGF1 stimulates glucose uptake and its action is through IGF1r (Pantaleon and Kaye 1996), but it has also a thermo-protective role. Previous studies showed that the exposure of bovine embryos to IGF1 improves both in vitro and in vivo development of heat-shocked embryos (Jousan and Hansen 2004; Block and Hansen 2007). The lower expression of IGFIr gene in heatshocked PA embryos suggests that IGF1 may not have the same thermo-protective role as that observed previously for in vitro fertilized embryos.

Despite the low number of genes evaluated in the current study, the altered gene expression in both heatshocked in vitro fertilized and parthenogenetic blastocysts indicates that heat stress at the beginning of development (44 hpia) can interfere in gene expression at later stages, what suggests a possible epigenetic effect induced by the high temperature, resulting in altered gene expression. Edwards and Hansen (1997) had already reported that the heat shock in earlier embryos could influence the gene expression by activating transcription before the major EGA. Nevertheless, the potential implication of such effects on embryo viability at later developmental stages and pregnancy still needs to be determined.

\section{Conclusion}

The heat shock at $44 \mathrm{~h}$ post-insemination/activation does not influence the development until $92 \mathrm{~h}$ postinsemination/activation (around 8- to 16-cell stages) but compromises the further embryo development, increase the apoptosis index and can disturb the expression of some genes at blastocyst stage in both in vitro fertilized and parthenogenetic embryos, indicating that the presence (as in fertilized embryos) or absence (as in parthenogenetic embryos) of sperm factors may not be critical for embryo thermosensitiveness.

\section{Acknowledgements}

Authors thank to CNPq and FAPEMIG (CVZ PPM 120/13) foundation for financial support.

\section{Conflict of interest}

None of the authors have any conflict of interest to declare.

\section{Author contributions}

We declare that all authors have made substantial contributions to the research and manuscript as follow: Camargo contributed to the conception and design of the experiments, data interpretation and analysis; Paludo and Quintao contributed to data acquisition of embryo development; Wohlres-Viana and Pereira contributed to data acquisition of gene expression; Carvalho and Gioso contributed to drafting the article and revision; and Viana contributed to data analysis and final revision of the manuscript. 


\section{References}

Barcelo-Fimbres M, Seidel GE Jr, 2007: Effects of either glucose or fructose and metabolic regulators on bovine embryo development and lipid accumulation in vitro. Mol Reprod Dev 74, 1406-1418.

Bertolini M, Beam SW, Shim H, Bertolini LR, Moyer AL, Famula TR, Anderson GB, 2002: Growth, development, and gene expression by in vivo- and in vitroproduced day 7 and 16 bovine embryos. Mol Reprod Dev 63, 318-328.

Block J, Hansen PJ, 2007: Interaction between season and culture with insulinlike growth factor-1 on survival of in vitro produced embryos following transfer to lactating dairy cows. Theriogenology 67 , 1518-1529.

Block J, Chase CC Jr, Hansen PJ, 2002: Inheritance of resistance of bovine preimplantation embryos to heat shock: relative importance of the maternal versus paternal contribution. Mol Reprod Dev 63, 32-37.

de Camargo LSA, Powell AM, do Vale Filho VR, Wall RJ, 2005: Comparison of gene expression in individual preimplantation bovine embryos produced by in vitro fertilisation or somatic cell nuclear transfer. Reprod Fertil Dev 17, 487-496.

Curry E, Ellis SE, Pratt SL, 2009: Detection of porcine sperm microRNAs using a heterologous microRNA microarray and reverse transcriptase polymerase chain reaction. Mol Reprod Dev 76, 218-219.

Dadoune JP, 2009: Spermatozoal RNAs: what about their functions? Microsc Res Tech 72, 536-551.

Dobson H, Tebble JE, Smith RF, Ward WR, 2001: Is stress really all that important? Theriogenology 55, 65-73.

Ealy AD, Howell JL, Monterroso VH, Arechiga CF, Hansen PJ, 1995: Developmental changes in sensitivity of bovine embryos to heat shock and use of antioxidants as thermoprotectants. J Anim Sci 73, 1401-1407.

Eberhardt BG, Satrapa RA, Capinzaiki CR, Trinca LA, Barros CM, 2009: Influence of the breed of bull (Bos taurus indicus vs. Bos taurus taurus) and the breed of cow (Bos taurus indicus, Bos taurus taurus and crossbred) on the resistance of bovine embryos to heat. Anim Reprod Sci 114, 54-61.

Edwards JL, Hansen PJ, 1997: Differential responses of bovine oocytes and preimplantation embryos to heat shock. Mol Reprod Dev 46, 138-145.

Grandjean V, Rassoulzadegan M, 2009: Epigenetic inheritance of the sperm: an unexpected role of RNA. Gynecol Obstet Fertil 37, 558-561.

Hamatani T, 2012: Human spermatozoal RNAs. Fertil Steril 97, 275-281.

Hansen PJ, 2007: Exploitation of genetic and physiological determinants of embryonic resistance to elevated temperature to improve embryonic survival in dairy cattle during heat stress. Theriogenology $\mathbf{6 8}$ (Suppl 1), S242-S249.

Haouzi D, Hamamah S, 2009: Pertinence of apoptosis markers for the improvement of in vitro fertilization (IVF). Curr Med Chem 16, 1905-1916.

Hardy K, 1997: Cell death in the mammalian blastocyst. Mol Hum Reprod 3, 919-925.

Immenschuh S, Baumgart-Vogt E, 2005: Peroxiredoxins, oxidative stress, and cell proliferation. Antioxid Redox Signal 7, 768-777.

Isom SC, Prather RS, Rucker EB III, 2007: Heat stress-induced apoptosis in porcine in vitro fertilized and parthenogenetic preimplantation-stage embryos. $\mathrm{Mol}$ Reprod Dev 74, 574-581.

Isom SC, Lai L, Prather RS, Rucker EB III, 2009: Heat shock of porcine zygotes immediately after oocyte activation increases viability. Mol Reprod Dev 76, 548-554.

Jin YX, Lee JY, Choi SH, Kim T, Cui XS, Kim NH, 2007: Heat shock induces apoptosis related gene expression and apoptosis in porcine parthenotes developing in vitro. Anim Reprod Sci 100, 118-127.

Jodar M, Selvaraju S, Sendler E, Diamond MP, Krawetz SA, 2013: The presence, role and clinical use of spermatozoal RNAs. Hum Reprod Update 19, 604-624.

Jousan FD, Hansen PJ, 2004: Insulin-like growth factor-I as a survival factor for the bovine preimplantation embryo exposed to heat shock. Biol Reprod 71, 1665-1670.

Kumar M, Kumar K, Jain S, Hassan T, Dada R, 2013: Novel insights into the genetic and epigenetic paternal contribution to the human embryo. Clinics (Sao Paulo) 68(Suppl 1), 5-14.

Lagutina I, Lazzari G, Duchi R, Galli C, 2004: Developmental potential of bovine androgenetic and parthenogenetic embryos: a comparative study. Biol Reprod 70, 400405.

Matwee C, Betts DH, King WA, 2000: Apoptosis in the early bovine embryo. Zygote 8, 57-68.

Memili E, First NL, 2000: Zygotic and embryonic gene expression in cow: a review of timing and mechanisms of early gene expression as compared with other species. Zygote 8, 87-96.

Mourot M, Dufort I, Gravel C, Algriany O, Dieleman S, Sirard MA, 2006: The influence of follicle size, FSH-enriched maturation medium, and early cleavage on bovine oocyte maternal mRNA levels. Mol Reprod Dev 73, 1367-1379.

Ostermeier GC, Miller D, Huntriss JD, Diamond MP, Krawetz SA, 2004: Reproductive biology: delivering spermatozoan RNA to the oocyte. Nature 429, 154.

Ostermeier GC, Goodrich RJ, Moldenhauer JS, Diamond MP, Krawetz SA, 2005: A suite of novel human spermatozoal RNAs. J Androl 26, 70-74.

Pantaleon M, Kaye PL, 1996: IGF-I and insulin regulate glucose transport in mouse blastocysts via IGF-I receptor. Mol Reprod Dev 44, 71-76.

Pantaleon M, Kaye PL, 1998: Glucose transporters in preimplantation development. Rev Reprod 3, 77-81.

Paula-Lopes FF, Hansen PJ, 2002: Heat shock-induced apoptosis in preimplantation bovine embryos is a developmentally regulated phenomenon. Biol Reprod 66, 1169-1177.

Pfaffl MW, Horgan GW, Dempfle L, 2002: Relative expression software tool (REST) for group-wise comparison and statistical analysis of relative expression results in real-time PCR. Nucleic Acids Res 30, e36.

Puri D, Dhawan J, Mishra RK, 2010: The paternal hidden agenda: epigenetic inheritance through sperm chromatin. Epigenetics 5, 386-391.

Ramakers C, Ruijter JM, Deprez RH, Moorman AF, 2003: Assumption-free analysis of quantitative real-time polymerase chain reaction (PCR) data. Neurosci Lett 339, 62-66.

Rieger D, Loskutoff NM, Betteridge KJ, 1992: Developmentally related changes in the metabolism of glucose and glutamine by cattle embryos produced and co-cultured in vitro. J Reprod Fertil 95, 585-595.

Sagirkaya H, Misirlioglu M, Kaya A, First NL, Parrish JJ, Memili E, 2007: Developmental potential of bovine oocytes cultured in different maturation and culture conditions. Anim Reprod Sci 101, 225-240.

Sakatani M, Alvarez NV, Takahashi M, Hansen PJ, 2012: Consequences of physiological heat shock beginning at the zygote stage on embryonic development and expression of stress response genes in cattle. J Dairy Sci 95, 3080-3091.

Satrapa RA, Nabhan T, Silva CF, Simoes RA, Razza EM, Puelker RZ, Trinca LA, Barros CM, 2011: Influence of sire breed (Bos indicus versus Bos taurus) and interval from slaughter to oocyte aspiration on heat stress tolerance of in vitro-produced bovine embryos. Theriogenology 76, 1162-1167.

Sendler E, Johnson GD, Mao S, Goodrich RJ, Diamond MP, Hauser R, Krawetz SA, 2013: Stability, delivery and functions of human sperm RNAs at fertilization. Nucleic Acids Res 41, 4104-4117.

Siffroi JP, Dadoune JP, 2001: Accumulation of transcripts in the mature human sperm nucleus: implication of the haploid genome in a functional role. Ital $\mathbf{J}$ Anat Embryol 106, 189-197.

Submitted: 24 Jun 2015; Accepted: 9 Oct 2015

Author's address (for correspondence): LSA Camargo, Embrapa Dairy Cattle Research Center, Rua Eugenio do Nascimento 610, Juiz de Fora, MG, 36038-330 Brazil. E-mail: luiz.camargo@embrapa.br 